\title{
Institutional Involvement of Parents in School Management, Brings the Albanian School Closer and Faster with the European Ones
}

\author{
Dr. Hysni Elezi \\ European University of Tirana \\ Dr. Tomi Treska \\ European University of Tirana
}

Doi:10.5901/jesr.2013.v3n7p437

\begin{abstract}
In developed countries there are identified some models of school-based management, especially related to the decisionmaking processes, based on the role that different actors have in it. This defines also the level of decentralization and school autonomy. In the framework of the decentralization reform in education area, even in Albania there are made positive steps towards transfer the authority into school level. The new law of pre-education system has created more opportunities especially for institutionalized involvement of parents in school management. Institutionalized involvement of parents in "school-based management", despite the progressive steps that have been made in Albania, still faces critical challenges to be functional. The focus of our research is identification of these challenges and barriers that parents face, recommending more legal opportunities, further support for parental capacity building, several means and mechanisms, for a real and effective role of parents in school management. This paper has been written based in surveys, interviews and focus groups discussions, developed in five urban schools and in four rural schools. The research showed that not all parents' rights in school have been considered; showed that even legal spaces are not fully applied, that institutions/organizations that represent parents' voice in school do not function properly etc.In order to address these issues this paper emphasis the need for more legal improvements, parental capacity building initiatives and also institutional strengthening of school-based parental structures.
\end{abstract}

Keywords: school-based management, parental involvement, challenges, Albanian pre-university education system, legislation

\section{Description of the context}

In this research study, we are based on similar models that exist nowadays in the developed countries of U.S. and Europe, on the involvement of all the groups of interest for the management and administration of the school. It is considered of high interest the implementation of the World Bank project "school-based management", and consistently the results of this implementation, in schools of several countries in our region, such as: Macedonia, Montenegro and Serbia. "School-based Management" is the systematic decentralization to the school level of authority and responsibility to make decisions on significant matters related to school operations within a centrally determined framework of goals, policies, curriculum, standards, and accountability. (Caldwell, B. J. (2005) pp 1-2).

Conceptually, it can be seen as a formal change of governing structures, which identifies individual schools as the primary units for the improvement. In this way, it is realized a redistribution of decision-making authority, because this authority is considered as the first instrument by means of which the educational improvement can be stimulated and supported. So, in this decentralization process, the responsibility and the decision-making authority on school operations is transferred to the principals, the teachers and the parents, sometimes even to the students and the members of the school community. (Barrera-Osorio, F.; Fasih, T.; Patrinos, H. A.; Santibáñez, L. (2009), pp 3).

The implementation of the "school-based management" is directly related to the improvement of the quality of education and the learning process, changing the school dynamics, changing the parents' behavior and involving them more in decision making and services provision for school. This approach aims to provide and improve services for the poor, and for all the categories, increasing their selection and participation in services delivery, giving the citizens a key role in the school management. (Barrera-Osorio, F.; Fasih, T.; Patrinos, H. A.; Santibáñez, L. (2009). pp 30).

In the developed countries, the basic idea that exists behind the "school-based management" is: "who works in the school building should have more control in the managing of what happens in this building." In the developing countries, this idea is less ambitious and is more focused on community and parents involvement in school decision-making 
process than putting this process completely under control. However, in both cases, the role of the central government in education is indisputable and the right definition of this role affects the conception and the implementation way of this movement activities. (The World Bank, (2007, pp 3-13).

This management way is identical with the decentralization of power, information, decentralization of knowledge and rewards and requires changing of the organizational structures, roles, policies, practical teachings and human resources management etc. (Sihono, T. \& Yusof, R. (2012), pp 151).

The existing various forms of "School-Based Management" are explained depending on the fact that who has the power to make decisions and what is the level of the decision making that is transferred to the school level. In some cases, School-Based Management, transfers the authority only to the principals or the teachers, in other cases it encourages, or mandates the parental participation.

From this point of view, there are four models of School-Based Management: (Leithwood, K.. \& Menzies, T. (1998). pp 325).

1) The Administrative Control: this (the Dutch model) transfers the authority to the school principal. It aims to make the school more responsible to the local education authorities by means of increasing the expenses efficiency on personnel and curriculum.

2) 2) The Professional Control (the Finnish model) transfers the decision-making authority to the teachers, intending better use of teachers' knowledge on school needs in the class level. In this way, the full participation of the teachers in decision-making can motivate them to work better by increasing teaching effectiveness.

3) The Community Control: (Mexico, New Zealand, Salvador, etc.) transfers the decision making to the parents or the community. In this model, it is assumed that the teachers and the managers to become more responsible to the parents' needs and the curriculum must reflect the local needs and preferences.

4) The Balance Control (Michigan, some states of Mexico, etc.) balances the decision making between the parents and the teachers, who are the two main actors in each school. The model aims to use the teachers' knowledge for the improvement of the school management, to make it more responsible to the parents.

In general, in the world, the existing models of School-Based Management are a mixture of the four models mentioned above. In most cases, the power is given to a formal legal actor in the form of the school board or the school management committee. Almost in all the versions of the School-Based Management, representatives of the community participate in these organizations. (Barrera-Osorio, F.; Fasih, T.; Patrinos, H. A. ; Santibáñez, L. (2009) pp 5).

The trends in School-Based Management are earlier, but in 1987 a pilot program was implemented in the public schools in Florida and the first results were not satisfactory. Two years later, the differences between the schools in the project and those out of the project began to appear. The schools in the project reached higher scores in more than half of the estimated factors. Sihono, T.\& Yusof, R. (2012) Implementation of School Based Management in Creating Effective Schools, 1 (4), pp 143.

Taking into consideration the positive results of the School-Based Management in the improvement of the education quality, many countries of the world are paying attention to the decentralization of the education system and the parents' and community involvement in school management.

The practice shows that School-Based Management is irreversible and the challenge is to achieve a balance between the centralization and the decentralization depending on the preferred or necessary values and on the human capacities at different levels to carry out their respective functions. (Brian J. Caldwell, (2005)).

The development trends of education in the world today, provide an evaluation and an important position of the parent in the education process. This role, associated with the parental involvement in the school problems to its governance, its administration and management, a global trend, from which not a single country can be excluded. $D i$ Gropello, E. (2006) no . 72).

In Albania too, the cooperation of the academic institution with the parents is a priority and the parents in this relationship are determined as the main partner of the school for the child's progress. The law on the Pre-university Education System, No. 69/2012 date 18/07/2012.

The studies carried out until now have demonstrated that the parental involvement and the democratic governance, are very essential to positively assist the learning process, to ensure the communication and the cooperation while respecting the diversity, to ensure a stable democracy for the future and to promote education for democratic. (Bäckman, E. \& Trafford, B. (2007) pp 27-28).

This involvement is important not only for the children but also for the parents themselves because it helps them with knowledge about the child, it helps them to transmit the good and positive traditions, also to be educated and self- 
educated continuously.

But, although there are priorities and advantages, the parental involvement in the organized structures within the school in the preuniversity education, and out of school, there have been weakness and shortcomings, which have affected directly the manner of the governance, administration and management of the school and therefore the school results. (CDE \& UNICEF. (2008) pp 41-43).

The relations between the level of the institutional involvement and the results of school management or governance, have been and still remain unharmonious and, naturally, the functioning of these institutions focused on increasing the school efficiency, is not in comply_with the required standards. The parental involvement in the education and school progress, existed also in the past, but it has been unorganized and many times either spontaneous or individual. In legal terms, it started with the Normative Provisions of 2002 (based on the law "For the Pre-university Education System", 1995), which determines the rights and the functions not only of the class and school Parents Councils, but also a new structure like the School Board with some rights mainly of advisory character. This involvement, too, based on the above law, has really functioned rarely or at all. For this, there are several reasons such as: inappropriate conception of the teachers and the school administrators to institutionalize the cooperation with the parents, the legal framework still does not favor sufficiently the parental institutional involvement, but on the other hand, even in those cases when it encourages with special provisions, those either are formally applied or set aside continuing to deal with old methods of school management and ending in insufficient level of parents awareness and training.

The new law on pre-university education system (2012) has created some space for the participation of the groups of interest, and in particular the parental involvement in school management. The law on the Pre-university Education System, No. 69/2012 date 18/07/2012.

The parental institutionalized involvement in "School-Based Management", despite the progressive steps made up to now, faces significant challenges to be functional.

\section{The methodology}

This is an empirical study. The study is conducted in a period when it has not yet started full implementation of the new Law on Pre-university Education System and is focused on the degree of the reflection in the school policies of the philosophy and practice of realization of the parental involvement, in the legal and organizational possibilities and the capacities the parents have to be involved in school management, and especially in decision making.

The sampling was carried out at random representatives of parents and teachers in urban and rural schools of preuniversity education. The quantitative component for this study is realized by means of the survey where 170 parents and 115 teachers of the urban schools in Tirana as well as 70 parents and 30 teachers of the rural schools in the suburbs of Tirana participated. The data were processed through SPSS program.

\section{Summary of the main findings}

The findings of this survey, based on the answers given by the respondents, are displayed in the following analysis made for each finding.

The questionnaire is completed by parents and school teachers who work with children of pre-university education.

\section{Data about the respondents}

\subsection{Participants surveyed by gender}

In Tirana, out of 170 parents interviewed: female responders were $63.1 \%$, while male responders were $36.9 \%$, while in Bathore out of 70 parents, $60 \%$ were male and $40 \%$ female.

For the surveyed teachers, who belong to the city schools in the basic education, we have this distribution according to the school cycle: grades 1-5, they are $40.7 \%$ and grades $6-9$, they are $57.4 \%$, while in village schools: grades 1-5, they are 10\%, grades $6-9$, they are $83 \%$ and grades $10-12$, they are $7 \%$. At the same time, the age of the teachers interviewed in the city varies with frequency (5.6\%) under 30 years old, and further (25.9\%) 31-40, (35.2\%) 4150 and over 50 years old they are (33.3\%), out of these $14.8 \%$ were male and $85.2 \%$ female. The teachers interviewed in the village are $50 \%$ female and $50 \%$ male, where $43 \%$ of them are over $50,30 \%$ are $41-50,23 \%$ are $31-40$ and only $3 \%$ under 30 years old. 


\subsection{Parents surveyed according to age group}

It is observed that the respondents to be distributed according to different age groups, with higher participation of the city parents of $31-40$ years old with $59.5 \%, 41$ - 50 with $28.6 \%$, under 30 with $9.5 \%$ and the last group which has the lowest number of children in school over 50 , which is $2.4 \%$. In the rural area, the largest age group of the participants is $41-50$ years old with $50 \%$, followed by $34 \%$ age $31-40,10 \%$ under 30 and only $6 \%$ of those over 50 .

\subsection{Education formation of the parents surveyed}

In order to identify the educational level of the parents, it was interesting to see in the survey also their educational formation which is as follows: In the city $50 \%$ of the responders were parents of high education, $39.3 \%$ of secondary education and only $9.5 \%$ of basic education. In the village, $50 \%$ of the respondents are of secondary education, $27 \%$ of 8 -years education and $23 \%$ of high education.

\section{Cooperation school - family}

The cooperation between the community of parents and other social partners with is sanctioned in Article 62 of Law No. 69, dated 21.06.2012 "For the Pre-University Education System in the Republic of Albania", which states: "The parents are the key partners of the educational institution in the progress of the child and the institution." In this article of the Law, besides the parents' duties, their rights are determined too. (Law on the Preuniversity education System, No. 69/2012 date 18/07/2011)

In this sense, the parent has the right to require the educational institutions to be informed of the educational legislation in force, the institution regulations and the curriculum the institution offers his child; to be informed of the conditions of safety, health and the institution's surroundings and to ask for their accomplishment in compliance with the standards specified by the Albanian legislation, to be informed of his child's activity in the institution and to give his consent for the complementary and extracurricular activities organized by the school; to be notified about the main directions of the institution activity and its achievements in comparison with similar institutions.

For this, the questionnaire was compiled in such a way to ask the parents in relation with teacher - parents meetings, principal - teacher- parents ones as well as their frequency and the topics of their information.

\subsection{Frequency of teacher - parents and principal - teacher- parents meetings}

In connection with the question of how often teacher - parents meetings are organized, it resulted by the survey that in the city schools teacher - parents meetings are at a higher percentage, (78\%) once a month. Parents who have never gone are $3 \%$, only once per semester $16 \%$, and those once a year is in lower value of $3 \%$.

In rural areas the situation is different and the results are not encouraging, because only $58 \%$ of parents say that meetings are organized once a month while $30 \%$ of them say/confess that these meetings are made only once a semester, $7 \%$ once a year and $4 \%$ answer 'I do not know'.

When they are asked about the frequency of teacher - parents meetings, about $91 \%$ of the teachers surveyed in the city state/confess that the meetings are organized once a month, $7 \%$ say that the meetings take place once a semester, the remaining $2 \%$ did not answer. The teachers working in rural area, $80 \%$ of them confirm that the meetings are held once a month, $13 \%$ say that they are organized once a semester and the others do not answer.

However, the frequency of principal - teacher - parents meetings presents another view. $32.1 \%$ of the parents surveyed in the city are of the opinion that such meetings are organized once a semester, $13.1 \%$ state that they are never organized and $17.9 \%$ reply that they do not know anything about this problem and $16.7 \%$ say that they are organized once a month. Even in the rural area, the highest percentage of $34 \%$ confirm that such meetings are organized once per semester, $26 \%$ say once a year, $19 \%$ say that they are never held, $13 \%$ do not know anything about these meetings and $9 \%$ confess that they are realized once a month.

The opposite happens with the teachers surveyed in relation with the frequency of principal - teacher - parents meetings. Thus, $64.8 \%$ of the teachers asked in the city declare that they are organized once a month, while the parents only $16.7 \%$. When the teachers in the village are asked about the frequency of these meetings, $40 \%$ of the teachers say that they are realized once a month (compared to $9 \%$ of the parents), $50 \%$ once a semester, $3 \%$ once a year and $7 \%$ do not know. Here, there is an obvious incompatibility between the parents' confessions and the teachers' ones there is 
somewhat a special distribution with incoherence between the values.

\subsection{Frequency of parents' information about their child's performance.}

Out of the data from the survey it results that $83.7 \%$ of parents surveyed in the city say that they are informed almost regularly once a month. A low percentage, $8 \%$, is of the opinion that parents information is carried out once a semester and $5 \%$ once a year. This shows that parents and teachers are interested in sharing information in connection with the child's performance. The data clearly show that the majority of the parents are concerned mainly about their children' results. In practice, for the majority of the parents, their contact with school is limited to their children's teachers. From the parents surveyed in the rural areas, $54 \%$ of them say that they are informed about their child's performance once a month, but $40 \%$ of them say that they are informed only once a semester, the rest $3 \%$ once a year and $4 \%$ are not informed at all. This indicates that the level of the cooperation between parents and teachers, even only about their child's performance is too low in the countryside in comparison with the city.

$63.0 \%$ of the teachers surveyed in the city say that they send the parents in written form the evaluation of their children's progress once a month, while $25.9 \%$ of them state once a semester. A low number of the teachers surveyed say that it happens once a year or never.

The results of the survey in the rural area show that $40 \%$ of teachers inform the parents once a month, $43 \%$ once a semester, $13 \%$ once a year and $3 \%$ never.

The fact that the parents in the urban and rural areas, state a higher percentage of information than the teachers confess about their information, is explained by the reasoning that the parents do not separate/distinguish the information they receive only from the teachers, but this amount of information they join it with what they receive when they go to school themselves.

\subsection{Parents information about the difficulties and problems the school their child attends, faces}

It is noticed that only $42.9 \%$ of the respondents in the city and $23 \%$ of parents in the village state that they are informed of the difficulties and problems of the school their child attends, once a month, while the rest are of the opinion that they are informed either once a semester or once a year. This shows the low level of parents' interest towards school problems as well as lack of confidence by the teachers and the school principals towards the parents whether the parents can help in the solution of the problems school encounters.

\subsection{What should be the frequency of the parent's meetings with the teachers}

It is observed that $96.4 \%$ of respondents in the city and $86 \%$ in the rural areas, are of the opinion that the frequency of parent's meetings with the teachers should be once a month. This shows that frequent contacts between the parents and the teachers are considered as something useful and in many cases they would make possible prevention of the problems or would facilitate their solution. However, this question does not show about the theme of the meetings between parents and teachers. We express our opinion that the majority of the parents who have responded this question positively, have considered only sharing of information with the teachers around their child's performance, and not necessarily about the problems the school faces. This conclusion is based on the current practice, which shows that not all the parents are interested in active participation in the school life.

\subsection{Frequency of the surveys organized by the school to get the opinions/approaches of the parents towards school problems}

In connection with the surveys conducted by the school in the form of polls, questionnaires, focus groups, round tables etc.., through which the school would understand parents' opinions/approaches in connection with the school problems, the results of the teachers surveyed are roughly distributed to five options offered: i) once a month; ii) once a semester; iii) once a year; iv) never and v) "I do not know". This shows that the teachers do not have a unified approach on this issue. It is positive the fact that the majority of responders in the village are of the opinion that such polls should be held once a semester. 


\subsection{Parents information about what happens at school}

The results of the respondents demonstrate that parents information of what happens in school are contradictory. This is expressed in two meanings: $63.1 \%$ of the parents surveyed in the city admit that they are informed once a week about what happens at school, while this figure for the parents in the village reaches $77 \%$. Secondly, these data do not match with the data given by the teachers. Only $42.6 \%$ of the teachers in the city accept this fact while in the village, that is confirmed by only $40 \%$ of them.

\subsection{Frequency of organizing of class parents council meetings.}

In connection with the question how often class parents council meetings are organized, it results that $41.7 \%$ of the responders in Tirana express that they take place once a month, $27.4 \%$ of the respondents say once a semester, and only $6.0 \%$ say once a year. But in Bathore, $36 \%$ of the responders declare that the meetings take place once a month, $24 \%$ once a semester and $13 \%$ say that such meetings are never held. Meanwhile, $17.9 \%$ of the respondents in Tirana and $14 \%$ in Bathore do not know anything about this issue, which shows an indifference of their role in school life.

\subsection{Priority topics that can be discussed with the teachers during parents - teacher meetings.}

Regarding the content of the discussions during the parents meetings, both in the city and in the village, as the most discussed issues we can list: progress in the lessons, children's behavior, children's motivation to improve their results, conditions of school surroundings, school activities, parents role in solving teacher - student conflicts, teacher - student communication and very little the scientific and pedagogical level of the teachers.

The question "Should the child be present all the times during the conversation in the parents - teacher meetings", $52 \%$ of responders answer positively, while $41 \%$ disagree that the child should be present in parents - teacher meetings.

\subsection{Participation of the parents - members of the School Parents Council.}

Regarding the request how often the parents - members of the Parents Council have participated in various school activities, round-tables with teachers and other principals on various class themes, providing assistance in teaching, financial support to the activities organized at school/class, offering ideas on creating a motivating atmosphere in class, only $15.9 \%$ of respondents in the city declare once a month. Meanwhile, $23.8 \%$ of them do not know anything about the issues mentioned above and more than $10: 48 \%$ have never participated. In the rural areas, $12.4 \%$ declare their participation in these activities once a month, $32.3 \%$ have never participated, while $15.6 \%$ do not know anything about the forms and methods of cooperation with school.

In the meantime related to this question, $59.3 \%$ of teachers surveyed in the city and $70 \%$ of teachers surveyed in the village answer that the parents take part in the organizing of class/school ceremonies once a semester, for the participation in the organizing of social activities at school/class level, respectively $38.9 \%$ in the city and $50 \%$ in the village answer once a semester, while $33.3 \%$ in the city and $40 \%$ in the village once a year; for providing assistance in teaching $9.3 \%$ in the city answer once a month, $16.7 \%$ once per semester, $18.5 \%$ once a year and $44.4 \%$ never. What attracts our attention is the difference in opinions between the parents and teacher respondents.

\subsection{What should be the participation frequency of the parents - members of Parents Council}

The survey results indicate that only $14.3 \%$ of responders in the city and $11 \%$ in the rural areas declare that they are interested to participate once a month in round-tables with the teachers and other principals on various class or school themes, $17.9 \%$ in the city and $16 \%$ in the village in various school activities, $22.6 \%$ in the city and $16.2 \%$ in the village for providing assistance in teaching. These findings do not indicate the willingness of the parents to exploit and increase their contacts with the teachers and school with all its problems.

\subsection{The importance of parents' opinions - members of Class/School Parents Council to improve the overall quality of education in school.}

The parental involvement in the selection and appointment of the teaching staff and school principals, nowadays it has 
become a legal obligation, what is worthwhile to mention that the parents' opinions should be taken into account.

The results of the survey with parents of the schools in Tirana show that $71.4 \%$ of the respondents suggest as very important the evaluation of teachers performance, $54.8 \%$ work for the selection of textbooks that the students use, $56.0 \%$ the development or updating of school policies and regulations, $50 \%$ the decisions made at class level, etc.. Meanwhile, about $47.6 \%$ consider somewhat important planning of social activities.

The question addressed to the teachers whether information on educational programs is sent to the parents, $24.1 \%$ of them respond once a month, $13.0 \%$ once a semester, $20.4 \%$ once a year, $13.0 \%$ never and $22.2 \%$ do not know anything about with this issue.

It is resulted significant differences expressed by the teachers in Bathore, who, 7\% do not know that the parents should be informed about the educational programs and $27 \%$ never send information to the parents: thus, over $16 \%$ of the teachers do not send information to the parents about school policies and regulations, while about $23 \%$ of them declare that they send such an information to parents once a year.

\subsection{Thoughts on some competencies of the Class/School Parents Council.}

The competencies that the parents the class/school parents council are: the proceeding of the educational - educative process, approval of the activities outside school, approval of the parents contributions, providing the consent for disciplinary measurements in school, assistance for school maintenance and assistance for school surroundings maintenance, cooperation with the local authorities and the communities, etc..

It is noticeable that the parents have more or less a clear view that the class/school parents' council has a determined role in school. The question has been open and the competencies of class/school parents council are formulated and defined by the parents in comply with the conception they have for them.

\subsection{Some of the alternatives on how to improve the functioning of class/school parents councils.}

Some of the alternatives for the improvement of the functioning of the parents councils from the parents surveyed are: decisions making at class level, planning of social activities, financial support for the planned activities and election of the parents' council by voting, etc. In this sense, besides others, it is recommended that their election should not be formal, but to be established in order to assist in the school problems (solving), as well as to clearly determine the tasks that must be followed during the school year.

\section{Recommendations}

- Compilation of a national strategy for parental involvement in school problems and in particular in its management. To prepare national training modules for the parents to raise their capacity, but also for the cooperation with partners in school management.

- To compile/develop the "Normative Provisions" of the New Law on the Pre-university Education System by pulling/collecting the opinions of all the groups of interest, as well as to delegate the competencies sanctioned in law, aiming at the accomplishment/completion of the 'decentralization of the education system' reform.

- With the preparation of the legal framework and the necessary human capacities, the process of decentralization in compliance with the "School-Based Management" concept, to start in some pilot schools, where the parents take on their responsibilities.

- To motivate the parents and their structures to increase their participation in decision - making, by attracting/collecting more and more their thought and providing them more competencies to evaluate the programs and the texts the children use.

- Sensitization and awareness about the important role the parents have not only for their interest to their child, but also about the responsibility they have for the progress of the entire education system in Albania.

- Awareness of the parents not only for the rights the actual Law on the Preuniversity Education System, but also the responsibilities that the law assigns them.

- Strengthening the elected parents structures, not only as a legal obligation, but as a condition and need for qualitative improvement of schools performance in Albania. 


\section{References}

Caldwell, B. J. (2005). School-Based Management. Education Policy Series 3, pp 1-2. Retrieved on May 15, 2013, from http://www.unesco.org/iiep.

Barrera-Osorio, F.; Fasih, T.; Patrinos, H. A. ; Santibáñez, L. (2009). Decentralized Decision-making in Schools: The Theory and Evidence on School-based Management. (c) World Bank, pp 3, 5, 30. Retrieved on April 6, 2013, from https://openknowledge.worldbank.org/handle/10986/2632

The World Bank, (2007). What Is School-Based Management? pp 3-13

Sihono, T.\& Yusof, R. (2012) Implementation of School Based Management in Creating Effective Schools, 1 (4), pp 143, 151.

Leithwood, K. \& Menzies, T. (1998). "Forms and Effects of School-Based Management: A Review." Educational Policy 12(3): 325

Di Gropello, E. (2006). "A Comparative Analysis of School-based Management in Central America", World Bank working paper no. 72

The law of the Pre-university Education System, No. 69/2012 date 18/07/2012.

Brian J. Caldwell, (2005). School-Based Management

Di Gropello, E. (2006). "A Comparative Analysis of School-based Management in Central America", World Bank working paper no. 72 Bäckman, E.\& Trafford, B. (2007). Democratic governance of schools. Publication of the Council of Europe, pp 27-28

CDE \& UNICEF. (2008). Study report "The situation of parents' involvement in education, in Albania" (in Albanian), pp 41-43. 